\title{
Social topos of church architecture
}

\author{
Irina Zarochintseva ${ }^{1, *}$, and Elena Lokonova ${ }^{1}$ \\ ${ }^{1}$ Volgodonsk Engineering Technical Institute the branch of National Research Nuclear \\ University“MEPhI", 73/94 Lenin St., Volgodonsk, 347360, Rostov region, Russia
}

\begin{abstract}
The article proves the idea that descendants are reminded about the history and culture of their country through the architectural forms of Church architecture. Church architecture expresses the power and greatness of folk feats, patriotism and love of freedom. Each church has its own history, includes the architectural style of its epoch, and occupies a certain position among the other religious buildings. Churches have cityforming significance and represent the sacred center of the city; as well they possess a sign, marking function in the area, which can be "read" as a common landmark in the social topes
\end{abstract}

\section{Introduction}

Architecture as an art form within the scope of spiritual culture, it forms an aesthetic human environment and expresses social ideas in art images. The historical development of the society defines the functions and types of facilities, technical construction systems, and artistic structure of an architectural building. Architectural space organization in settlements, the cities and towns construction, the settlement system regulation- all these segregated into a particular sphere - urban planning.

Church architecture is not the same what is civil architecture. It includes important symbolic meanings; it has other functions, tasks, design features. The church building cannot be built only on the basis of the three-dimensional and stylistic considerations. Modern church architecture gradually becomes the object of serious study; there even appear standards and norms for church designing.

The Orthodox Churches were built in different ways, but each church symbolically corresponded to some church doctrine. Sochurches in the form of a cross meant that the Christ Cross was the basis of the Church and the ark forpeople'ssalvation; round churches meant the Church and the Heavenly kingdom eternity, as a circle is a symbol of eternity, that has no beginning and no end; churches in the form of an octagonal star marked the Bethlehem star and the Church as a shining beacon of salvation in the life to come, the eighth century, for the period of Earth's history was calculated in seven long periods centuries, and the eighth century meant the eternity in the Kingdom of God, the life of the next century. There were spread so-called ship churches in rectangular form, often close to the square, with extended eastward rounded altar absis protrusion (Fig.1).

${ }^{*}$ Corresponding author: ivzarochintseva@,mephi.ru 


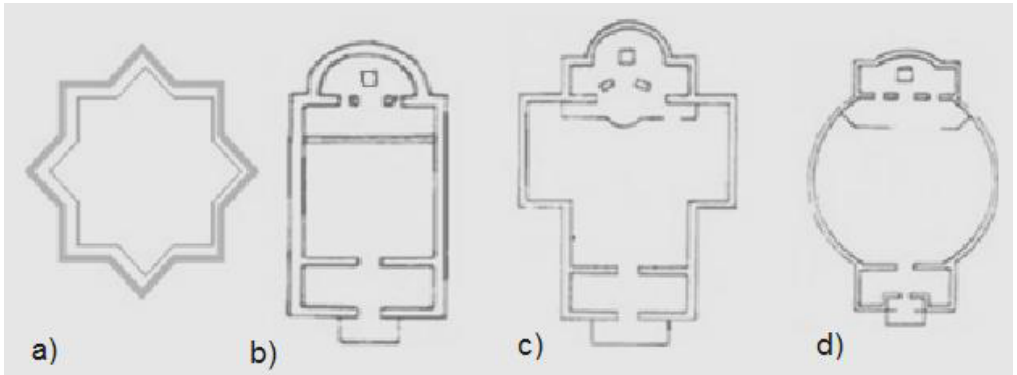

Fig.1. Architectural church types: a) octagonal form, b) rectangular (ship), c) form cross form d) round form

The relevance of the topic is determined by the fact that the architecture, as well as every form of art, has an inherent professional language of architectural forms which is inextricably connected with human worldview, with his spiritual organization.

That is why the meaning and significance of Orthodox Church architectural forms can be understood only by considering the Church in its idea of Divinedispensation on the basis of the Holy Scriptures and the works of the Holy Fathers of the Church. The descendants are reminded about the history and culture of their country through the architectural forms of Church architecture.

Architecture historicism is not only a formal artistic expression of the epoch, but also the result of a positive and value orientation, the historical basis for social progress [1]. The purpose of this paper is to show that Church architecture is a form of socialtopos that has the city-forming meaning.

\section{Metods}

The methodological bases of the study are the traditional approaches in the humanitarian knowledge, such as, for example, cultural, socio-historical.

Cultural approach serves as a method to study the Russian culture phenomenon, in particular the Orthodox Church. It allows, while studying, not to pay attention to hierarchical division into religious and secular, but to assess the church according to its meaning in the spiritual experience of mankind, thus characterizing its mental content. Thus, the cultural approach gives an opportunity to track internal links between the cultural epochs, keeping an eye on similarities and differences between forms at different stages of Russian culture development.

Socio-historical approach allows us to identifying the cultural context religious, philosophical, scientific, aesthetic world view, revealing their historical continuity; it focuses moment of individuality and uniqueness of the Orthodox Church cultural phenomenon, which allows you to elicit specific features in different historical periods of the Russian culture development.

To write the given paper there were also used the basic scientific object comprehension methods such as analysis, synthesis, generalization, abstraction, analogy.

The theoretical basic layer of the paper is based on the principles of historicism, specificity, objectivity, consistency, systematicity, rationality.

Since the Orthodox Church is an indivisible religious and aesthetic unity, so to disclose the architectural form symbolism and specific architectural details it is necessary to refer to the Orthodox Church idea consideration. 


\section{The church architecture as a symbolic expression of the man and the world image}

The church symbol finds its reflection in the church architecture as a symbolical expression of the man and the world images, their existential organization. Architectural church construction isn't individualistic, but it is almost always utilitarian therefore it is objective. Its functions go beyond subjective expression of the personal creative beginnings [2]. The church architecture passed a multi-stage and thorny road in its development before to find its own style, its unique lines peculiar only to the Russian architectural art. But anyway there are certain church architecture canons which can't be violated as the sense of sacred (sacral) can be broken.

Ancient architects often built churches in the image and likeness of the man. Under the highest and therefore the biggest cross there rises the main dome - like the head of the church; under the main dome there are walls -likewide shoulders; windows, like eyes, look from under the codes - strict eyebrows. The three-part organization of the church symbolizes the man himself consisting of three parts: a) body; b) soul; c) spirit according to the Holy Scripture doctrine and St. Fathers of Church.

The space and time symbolism is embodied in church architecture and remains basically the same until the 20th century. The cubic church construction forms symbolize the earth, a spherical dome means "firmament". The number of domes has not only functional, but also symbolic meaning [2]. The internal space of church expresses the symbolical East-West opposition that means a temporal orientation from the beginning to End Times. There is a certain symbolical sense in the figure position and size, geometrical forms and colour scheme in painting. The cube means material, static, temporal, the sphere denotes fiery, mobile, and eternal. Different nimbus colour shine over the heads of sacred characters is a symbol of their abidance in various heavenly spheres.

These Christian symbol (earth and fire) sources go back to the antique idea of primary elements. The earth and fire simulacrum in one plane on frescos, their embodiment in church architecture was perceived by the old Russian people consciousness as unity of cosmic universum in which transient time and finite space are combined with eternity and infinity.

Since the 4th century Christian churches mostly took a form of an octagon and a circle. So, according to EvseviyKesariysky, Constantine the Great constructed an octagonal church in Antiokhi; St. Elena constructed a round church on Golgotha. It is a symbolical reminder that the Christ's church is similar to a guiding star, it shines in the world and will exist till End Times, as the circle is an eternity symbol.

The church symbol in its original sense represents itself the ship floating as a saving haven, among the ups and downs of life storms. Like the ship, the church should have a "fore" and "stern" part that helps to orientate in its structure, on its way from the West to the East[3].

The church is often compared with Noah's Ark in which they succeeded to find salvation among rough waters of this world, or with Pyotr's Boat in which Disciples of Christ were floating together with Christ Redeemer to the new harbour, to Heavenly Jerusalem. As the ship image is a symbol of Church, it is not incidentally that the main space of the church is called "nave" or "naos" that means "ship" in Greek.

As for church architecture, it should be noted that it had the symbolical character that was strictly observed, at least, in the main and internal parts. If the Old TestamentTabernacle and Temple of Solomon had converting character and a certain division of the parts, mentioned in the New Testament Revelation, now it is expressed more precisely and carries a deeper symbolical meaning. Antique and Abrahamic traditions influenced Christian church architecture and thus have caused distinction between western- 
dynamic and eastern-static church models. Three parts in Temple of Jerusalem: the yard, the temple and sancta sanctorum are also preserved in the Christian church scheme: the church porch, the church (naos, nave) and the altar as shown in Figure 2.



Fig.2. Christian church scheme; 1 - the altar, 2 - the church (naos, nave), 3 - the church porch

\section{Church structures as space and historical landmarks}

Each church has its own history, includes the architectural style of its epoch, and occupies a certain position among other religious buildings. Specific patterns of the church architecture history, for example, in Moscow support the idea that the Church is a symbol of various historical events.

Thus, the Church of the Nativity of the Holy Motherin Old Simonov (Moscow region) is a historic wooden building, built in 1370, where bodies of the warriors Oslyabaand Peresvet killed in the Battle of Kulikovo had been buried. Simonov monastery based at the church was moved to another locations time passed. The church itself turned into a parish church and there was formed a settlement around it with craftsmen, carpenters, blacksmiths, who served in Simonov Monastery [4].

The area, where the Church of the Virgin Mary of Tikhvinis located in Alekseevskoevillage, is known since ancient times. In the XVII centuryvillage Kopytovobelonged to Prince D.T.Trubetskoy. Tsar Alexei Mikhaylovich built the "en route imperial palace "in this village that was a resting place on the way to the TrinityLavra of St. Sergius. The "en route imperial palace"served as the first staging post of the Tsar on the way to the monastery.

Christ the Saviour Cathedral in Moscow - "the great Moscow cathedral, a remarkable monument of Russian architecture, the creation of a national-patriotic and artistic Russian genius, the noble wreath of the grateful posterity on the grave of famous fighters and heroes who laid down their lives for their friends and for their land in a terrible hour of 1812Patriotic war [5], it was conceived as a monument to the Russian people heroism.

The main ideas, according to the architect Charles Vitberg, were necessarily to be embodied in stone, and they consisted in the following: firstly, this church, "was to satisfy the tsar's demands and was worthy of the people of Russia" that still had not had the monument, which would correspond to "its Height", and secondly, that its stones were "speaking the ideas of the religion of Christ." The arrangement of the church itself would constitute the soul of the man, for it is said: "Therearethe House of God and the Holy Spirit dwells in thee" [6]. According to K. Vitberg, the trinity of the Man - body, soul, spirit -was expressed in the idea of the church itself, which consists of three thrones, symbolizing the Incarnation, the Transfiguration and the Ascension. 


\section{Church as a social city-forming topos}

Orthodox Churches for centuries acted as a city-forming socialtopos [2]. I.O. Trifonova in thepaper"City as a sacred space" [7] notes that "... in the city the Church fixed the center, which in this position had the city-forming significance." Sometimes, the name of the city itself claimed the positioning of the city in a particular social environment. So, A.U.Dvornichenkomentions a quote from the Service to Abraham of Smolensk: "Verily Vyshegorodis named: supreme and above all the city" [8].

Churches of all kinds should awaken high spiritual senses in others; force to forget the earthly, material. That is why the churches in most cases were constructed on the hills.

The church wasthecore of the city. For example, the church of St. Sophia of Kiev in the city was necessary for "synod of holiness and blessing of the city" [9], it acted as a "source of power, which purifies, illuminates the space, uniteschaotical crowds into the tribes, the peoples ..." [10].

The church in any Russian city set the image of this city. Likhachev noted that "... Russian land appears in the annals ... likea form of a geographical map ..., where cities sometimes are replaced by their symbols - patron churches, where Novgorod is spoken of as Sophia, Chernigov - as Savior and so on "[11].

This can be traced in the book miniatures, depicting, for example, Novgorod as a "many-headed church, surrounded by a fortified wall" [12]. S.S.Averintsevspeaking of Kiev underlined that "... St. Sophia Cathedral in Kiev is such a part of the city that equals its whole" [13].

It is also necessary to mention that it was the church that defined the sacred space of the city. For example, on the edge of Suzdal there was the monastery of Presentation of the Mother of God. From this spot all the churches inside the city were built in the following sense successions: Nikolsky Gate - Church of Joachim and Anne, parents of the Mother of God - Cathedral of the Nativity of the Mother of God - Church of the Assumption of the Mother of God - Ilyinsky Gate. Further, northwest from the Church of Nativity another succession began: Cathedral of the Nativity of the Mother of God - Church of the Sign Church of Deposition of the Holy Robe - Church of the Intercession of Our Lady. These church successions let us trace the entire life-story of the Holy Mother.

There is a parallel line in the city, northern one: Spassky Church - Transfiguration Church - the Church of Lazarus -Candlemas-Churchof the Exaltation of the Holy Cross Church of the Resurrection. This series represents, along with the biography of the Holy Mother, the story of Christ. So, through the certain location of the churches the city is represented as the Gospel text[3].

In addition, the church was a topographical landmark by which you could freely travel, without fear of getting lost. This is due to the fact that in Russia all churches were located quite close to each other, that is, a traveller could see their domes that served as a landmark. A traveller, who stopped at a church, could easily determine where he was. Crosses disposition on the church dome allowed determining the correct cardinal direction as a compass did. A traveller, driving up to some village, could accurately tell where he was. If a church dome could be seen above the roofs so it was a village. Hamlets had no churches; there were small chapels [14].

In cities, a great number of churches was explained by the fact that any social group wished to have its own church. [15]. this was reflected in the tradition of the so-called corporate churches for certain professional groups, streets, parts. For example, in Novgorod merchants had their patron St. John the Baptist Church, which they maintained according to the Charter of Prince VsevolodMstislavovitch. Church of St. Basil of Caesarea on 1st Tverskaya Street in Moscow (now defunct), was founded by Moscow coachmen of Tverskayaslobodain the XVI century. 


\section{Conclusions}

Thus, we can draw the following conclusions:

1) Descendants are reminded about the history and culture of their country through the architectural and sculptural forms of church architecture.

2) The churches are the symbol of the national culture. In traditional symbolic forms of churches architecture expressed the cherished dreams of the people, the power and greatness of soul, patriotism and love of freedom.

3) The harmony of architectural forms and proportions of the church represent the deep symbolism of the human and poetic feeling.

4) The church is a topographic landmark for a travelling man.

5) The church architecture represented the sacred space of the city as a whole, but the center, as a rule, was fixed by the main church, which in this position had the city-forming significance.

\section{References}

1. I.V. Zarochintseva, Phenomenological image of the artistic culture of the XVII century Germany, PhD thesis, Rostov-on-Don, 17 (2004)

2. E.L. Lokonova, Church as a cultural and symbolic text, PhD thesis, Rostov-on-Don, 26, (2004)

3. E.L. Lokonova, Sacral-cultural significance of the Temple symbolism, Historical, philosophical, political and juridical sciences, cultural studies and art history, Questions of theory and practice, Tambov, Pub. Diploma, 8, 137-140 (2016)

4. O.R. Polonsky Under the temples arches of Moscow (Russian church architecture in the country's history and culture) (Knowledge, Moscow, 1990)

5. URL: - http://ortox.ru/news-newsd-759.html (reference date 30/05/2016)

6. M.S. Mostovsky, The Cathedral of Christ the Savior in Moscow (1918 edition, Profizdat, Moscow, 1997)

7. URL: - http://www.rusarch.ru/trifonova1.htm (reference date 01/20/2016)

8. A. Yu. Dvornichenko, Genesis and development of feudalism in Russia. Problems of national and world history 10, 25(1987)

9. V.V.Milkov,Understanding the history of Ancient Rus (St.-Petersburg, 2003)

10. M.B. Plyukhanova, Lotman collection (Moscow, 1997)

11. D.S.Likhachev,Poetics of Old Russian literature (Moscow, 1979)

12. V.D. Cherny, Veliky Novgorod in ancient book-miniature. History and culture of the ancient town (Moscow, 1989)

13. S.S.Averintsev,From the history of Russian culture(Moscow,.2000)

14. G.G. Ershova, The model of the world as an information space: col. of articles on Knorozovsky readings materials, (Moscow, 2000)

15. A.P. Dobroklonsky, Guidance on the history of the Russian Church (Moscow, 1999) 